\title{
Skrifbeskouing en Skrifhantering: Marcus Borg en die Hervormde Kerk -'n Vergelykende studie
}

\begin{tabular}{|c|c|}
\hline \multicolumn{2}{|c|}{$\begin{array}{l}\text { Author: } \\
\text { Ernest van Eck }{ }^{1}\end{array}$} \\
\hline \multicolumn{2}{|c|}{$\begin{array}{l}\text { Affiliation: } \\
\text { 1Department of New } \\
\text { Testament Studies, Faculty of } \\
\text { Theology, University of } \\
\text { Pretoria, South Africa }\end{array}$} \\
\hline \multicolumn{2}{|c|}{$\begin{array}{l}\text { Research Project Details: } \\
\text { Project Leader: E. van Eck } \\
\text { Project Number: } 2400030\end{array}$} \\
\hline \multicolumn{2}{|c|}{$\begin{array}{l}\text { Project Description: } \\
\text { This research is part of the } \\
\text { project 'Socio-cultural } \\
\text { Readings', directed by Prof. } \\
\text { Dr Ernest van Eck, } \\
\text { Department of New } \\
\text { Testament Studies, Faculty of } \\
\text { Theology, University of } \\
\text { Pretoria. }\end{array}$} \\
\hline \multicolumn{2}{|c|}{$\begin{array}{l}\text { Corresponding author: } \\
\text { Ernest van Eck, } \\
\text { ernest.vaneck@up.ac.za }\end{array}$} \\
\hline \multicolumn{2}{|c|}{$\begin{array}{l}\text { Received: } 26 \text { Apr. } 2017 \\
\text { Accepted: } 10 \text { June } 2017 \\
\text { Published: } 22 \text { Aug. } 2017\end{array}$} \\
\hline \multicolumn{2}{|c|}{$\begin{array}{l}\text { How to cite this article: } \\
\text { Van Eck, E., 2017, } \\
\text { 'Skrifbeskouing en } \\
\text { Skrifhantering: Marcus Bor } \\
\text { en die Hervormde Kerk -'n } \\
\text { Vergelykende studie', HTS } \\
\text { Teologiese Studies/ } \\
\text { Theological Studies 73(1), } \\
\text { a4606. https://doi.org/ } \\
\text { 10.4102/hts.v73i1.4606 }\end{array}$} \\
\hline \multicolumn{2}{|c|}{$\begin{array}{l}\text { Copyright: } \\
\text { (C) 2017. The Authors. } \\
\text { Licensee: AOSIS. This } \\
\text { is licensed under the } \\
\text { Creative Commons } \\
\text { Attribution License. }\end{array}$} \\
\hline \multicolumn{2}{|l|}{ Read online: } \\
\hline 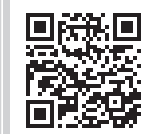 & $\begin{array}{l}\text { Scan this QR } \\
\text { code with your } \\
\text { smart phone or } \\
\text { mobile device } \\
\text { to read online. }\end{array}$ \\
\hline
\end{tabular}

Marcus Borg, one of the most prominent New Testament scholars in the past four decades, is considered by many in the Netherdutch Reformed Church of Africa as a liberal scholar. His understanding of the origin of the Bible, the way he interprets the Bible, and what he sees as the status and function of the Bible, should therefore be dismissed. A comparison of Borg's point of view on these topics with that of the points of view of the Netherdutch Reformed Church of Africa, however, indicates that Borg's understanding of these matters differs not even marginally from that of the Netherdutch Reformed Church of Africa. In a certain sense, Borg could therefore be described as a theologian who fits the mould of what is understood in the Netherdutch Reformed Church of Africa as a responsible approach to and interpretation of the Bible.

\section{Inleidend}

Marcus Borg, wat op 21 Januarie 2015 oorlede is, kan met reg beskou word as een van die mees prominente Nuwe-Testamentici die afgelope vier dekades. Borg se verskyning op die teologiese toneel het min of meer saamgeval met die totstandkoming van die Jesus Seminar in 1985 onder leiding van Robert Funk. Die Jesus Seminar word algemeen beskou as een van die stimuli wat aanleiding gegee het tot die sogenaamde vyfde fase in die ondersoek na die historiese Jesus, te wete die Renewed Quest. In hierdie Quest was die fokus nie meer op die woorde van Jesus nie, maar op Jesus as historiese figuur in sy Joodse konteks. ${ }^{1}$ In 1987, twee jaar nadat die Seminar met sy aktiwiteite begin het, het Borg sy eerste boek oor die historiese Jesus, getitel Jesus, a new vision: Spirit, culture, and the life of discipleship (kyk Borg 1987) gepubliseer. In vorige publikasies oor Jesus het Borg Jesus getipeer as ' $n$ sosiale profeet en inisieerder van 'n vernuwingsbeweging. In hierdie werk brei hy sy verstaan van Jesus uit: Jesus was ook 'n charismatiese heler ('heilige persoon') en 'n subversiewe wysheidsleraar. ${ }^{2}$

Borg se verstaan van Jesus as historiese persoon het, soos die aktiwiteite van die Jesus Seminar, hewige debatte in die kringe van Nuwe-Testamentici, die pers en elektroniese media uitgelok (ook op plaaslike bodem), veral na sy besoek aan Suid-Afrika en, spesifiek, die Fakulteit Teologie, Universiteit van Pretoria, in Oktober 1995. In verskeie gesprekke na Borg se besoek en lesings waarin die skrywer van hierdie bydrae teenwoordig was, was die beoordeling van Borg se verstaan van Jesus (met enkele uitsonderings) negatief. Woorde soos 'ongelowige' en 'ketter' was aan die orde van die dag. ${ }^{3}$ Ook sy verstaan van die gesag van die Bybel, en hoe die Bybel geïnterpreteer behoort te word, wat as modernisties-krities gesien is, het skerp kritiek uitgelok. Dit is interessant dat hierdie debatte nooit werklik die kerklike pers van die Nederduitsch Hervormde Kerk van Afrika (hierna Hervormde Kerk) gehaal het nie. Ten spyte van die hewige kritiek op en afwysing van Borg se hermeneutiese uitgangspunte en teologie, het daar net een artikel in Die Hervormer verskyn met as inhoud 'n verduideliking van Borg se verstaan van die opstanding (kyk Van Wyk 1995:2). ${ }^{4}$ Die stilte oor Borg se verstaan van Jesus, sy Skrifbeskouing, en wyse van Skrifhantering in die kerklike pers van die Hervormde Kerk was egter kontrasterend met gesprekke in die wandelgange van die Kerk. Hier was die gesprek afgehandel en die boodskap was duidelik - Borg was 'n ongelowige en liberale wetenskaplike, en vir sy idees is daar nie plek

1.Vir'n beskrywing van die vyf fases waarin die soeke na die historiese Jesus tradisioneel ingedeel word, asook die spesifieke fokus van die Renewed Quest, kyk Tatum (1999:91-106).

2.Hierdie verstaan van Jesus het Borg later in meer detail uitgewerk in sy Meeting Jesus again for the first time: The historical Jesus and the heart of contemporary faith. The meaning of Jesus: Two visions (geskryf saam met N.T. Wright), en Jesus: Uncovering the life, teachings, and relevance of a religious revolutionary (kyk resp. Borg 1994; 2006; Borg \& Wright 1999). Die skrywer van hierdie bydrae is nog steeds van oordeel dat laasgenoemde een van die beste boeke in populêre vorm is wat oor die historiese Jesus geskryf is.

3.Dit, ten spyte van die feit dat Borg tot die einde van sy lewe intens betrokke was by en aanbid het in die Episkopale Kerk, die denominasie waarin sy vrou as priester georden is.

4.In hierdie aanbod oor Borg se verstaan van die opstanding is dit nie duidelik of die skrywer met Borg saamstem of van hom verskil wat Borg se verstaan van die opstanding betref nie (kyk Van Wyk 1995:2). 
in die eksegese en verkondiging van die Kerk nie. Alhoewel hierdie gesprekke in die Kerk nie op skrif gestel is nie, blyk dit dat die Kommissie van die Algemene Kerkvergadering, in sy Herderlike Skrywe van Maart 1997, tog negatief op onder andere Borg se standpunte gereageer het (kyk Kommissie van die Algemene Kerkvergadering 1997:1-3).

Maar is dit waar? Het soveel deelnemers aan hierdie gesprekke nie toe die baba met die badwater uitgegooi nie? Die antwoord hierop is, na my oordeel, ja - veral as daar in meer detail na Borg se Skrifverstaan en Skrifhantering gekyk word. Kennis hiervan bring 'n verrassing na vore wat vir baie ondenkbaar sal wees - Borg was 'n goeie Hervormer! Borg se siening van die gesag van die Bybel en die wyse waarop hy die tekste van die Bybel hanteer in sy interpretasie daarvan, kom feitlik presies ooreen met die Hervormde Kerk se amptelike standpunt oor die gesag van die Bybel, en hoe die Bybel gelees en gehoor behoort te word. Hierdie wyse van die interpretasie van die Bybel is verder nie net duidelik sigbaar in die eksegese van die Bybelwetenskaplikes van die Kerk nie, maar ook dit wat studente van die Kerk oor Skrifbeskouing en Skrifhantering aan die Fakulteit Teologie in die Bybelwetenskappe geleer word.

Vervolgens word eerste aandag gegee aan Borg se verstaan van die gesag van die Bybel en die wyse waarop hy die Bybel interpreteer. Daarna word 'n vergelyking getref tussen Borg se Skriflesing en Skrifhantering en die van die Hervormde Kerk. Voor daar met ' $n$ aantal slotopmerkings volstaan word, word aandag gegee aan wat Borg met die historiesmetaforiese verstaan van die Bybel bedoel en hoe hierdie verstaan van die metaforisiteit van die Bybel deur sommige Bybelwetenskaplikes van die Hervormde Kerk in hulle lees van die Bybel toegepas word.

\section{Skrifbeskouing en Skrifhantering: Marcus Borg}

Borg se Skrifbeskouing en Skrifhantering kan aan die hand van drie temas beskryf word, te wete die oorsprong van die Bybel, hoe die Bybel geïnterpreteer behoort te word, en dit wat die funksie of gesag van die Bybel is.

Wat eersgenoemde betref, is Borg van die oortuiging dat die Bybel die produk is van twee historiese geloofsgemeenskappe: antieke Israel en die vroeë Christelike beweging. Die Bybel het dus nie 'n 'goddelike oorsprong' nie, maar 'n menslike; die Bybel is ' $n$ menslike reaksie en besinning oor God se handelinge met gelowiges in die wêreld (Borg 2003:13-15, 45-46). Hierdie verstaan van die oorsprong van die Bybel, aldus Borg, ontken nie die bestaan of werklikheid van God nie. Inteendeel, hy stel dit soos volg:

The Bible is the product of two historical communities ... it is a human product, not a divine product. This claim in no way denies the reality of God. Rather, it sees the Bible as the responses of these two communities to God. As their response to God, the Bible tells us how they saw things. Above all, it tells us how they saw their life with God. It contains their stories about God's involvement in their lives, their laws and their ethical teachings, their prayers and praises, their wisdom about how to live, and their hopes and dreams. It is not God's witness to God (not a divine product), but their witness to God. (Borg 2003:45)

So verstaan, oordeel Borg, bevat die Bybel nie God se 'absoluut geopenbaarde waarheid' nie, maar gelowige nadenke oor God wat dikwels kultureel bepaald is: die verstaan van God vind plaas vanuit 'n bepaalde plek en tyd, en word uitgedruk deur middel van taal en kulturele konsepte wat deel was van die wêreld van die skrywers van die onderskeie Bybelboeke (Borg 2003:45). Vir Borg beteken hierdie egter nie dat die Bybel nie geïnspireer is nie. In terme van sy verstaan van die oorsprong van die Bybel, beteken dit dat die Gees van God so in mense gewerk het dat hulle oor God getuig het soos wat hulle gedoen het. Die fokus is dus nie op woorde wat geïnspireer is nie, maar op mense wat deur die Gees van God aangeraak is, en daarom oor God getuig het soos hulle het (Borg 2003:46; kyk ook Borg 2001:21-28).

Ten spyte van bogenoemde verstaan van die oorsprong van die Bybel, hoe die Bybel geïnterpreteer behoort te word, en dit wat die funksie of gesag van die Bybel is, beskou Borg (2003:47) die Bybel as 'n sakrale geskrif ('sacred scripture') en die Woord van God (Borg 2001:31-34). Die Bybel is egter nie 'heilig' omdat die oorsprong daarvan goddelik is nie, maar omdat die vroeë kerk, in die proses van kanonisering, die Bybel as heilig verklaar het. Deur dit te doen, het die vroeë kerk die boeke in die Bybel 'n besonderse status gegee - 'n ontwikkeling en proses waarmee Borg gemaklik is. Die Bybel, stel hy daarom, is die fondasie van die Christelike godsdiens, dit wat die Christelike geloof se identiteit bepaal, en alleen dit wat bepalend is vir die Christelike etiek (Borg 2003:47; kyk ook Borg 2001:29-31). ${ }^{5}$

Wat Skrifhantering (die wyse van interpretasie) betref, oordeel Borg dat twee sake belangrik is wanneer dit kom by die interpretasie van die Bybel. Omdat die Bybel die historiese produk van twee antieke gemeenskappe is, was die boeke in die Bybel nie in die eerste plek vir ons (die moderne leser) geskryf nie, maar vir die gemeenskappe wat die tekste geskep het. Om hierdie rede moet die boeke in die Bybel histories benader word, dit wil sê, die boeke moet in die eerste plek in terme van hulle oorspronklike historiese kontekste geïnterpreteer word. 'n Historiese benadering tot die Bybel, volgens Borg, gaan in die eerste plek dus om te bepaal wat die teks in sy eerste historiese konteks beteken het, en wat die teks aan sy oorspronklike geadresseerdes wou kommunikeer (Borg 2003:48). Historiese konteks, interessant genoeg, sluit vir Borg nie net die sosiohistoriese konteks van die skrywer en eerste lesers van 'n bepaalde boek in nie. Historiese konteks het ook te make met die antieke literêre konteks van 'n teks (die betrokke teks se verband met ander

5. Borg (2003:47) formuleer dit soos volg: As sacred scripture it functions as: (1) Our foundation document: the foundation upon which Christianity is build without foun the structure will fall into ruins. (2) Our identity document: its stories and wisich the structure will fall into ruins. (2) Our identity document: its stories and visions are to shape our sense of who we are and of what our life with God is about. (3) Our 'wisdom tradition': in its comprehensive sense, 'wisdom' concerns the two most central questions of life: What is real? And how shall we live? 
tekste in dieselfde dokument), en die teks se kanonieke konteks (die teks se verband met ander boeke in die Bybel). Ten slotte sluit historiese konteks ook die moontlike geskiedenis agter die teks in (Borg 2003:49).

Tweedens is dit vir Borg belangrik dat die Bybel meer-asletterlik of meer-as-feitlik gelees moet word, aangesien die tekste in die Bybel dikwels metafories van aard is. Met metafories bedoel Borg die 'meer-as-letterlike' betekenis van tekste. Volgens hom is die taal wat dikwels in die Bybel gebruik word metafories van aard, en hy stel dit soos volg: 'It [die tekste in die Bybel] is not very much concerned with the historical factuality of the Bible's stories, but much more with their meanings' (Borg 2003:13). ${ }^{6}$ Volgens Borg is daar verskeie soorte metafore wat in die Bybel gebruik word. Die Bybel gebruik, byvoorbeeld, duidelike metaforiese taal wanneer daar van God se hande en voete gepraat word, terwyl ons weet dat God heel waarskynlik nie hande en voete het nie. Tweedens bevat sommige van die vertellings in die Bybel beide geskiedenis en metafoor ('narratives that metaphorize history'; kyk Borg 2001:45). Die uittog uit Babilon, as voorbeeld, het werklik gebeur, maar word so vertel dat dit oor meer handel as historiese gebeure; dit kommunikeer ook iets van die mens se verlorendheid en hoe God uitred. Ander vertellings weer, soos die skeppingsverhale in Genesis 1 en 2, is volgens Borg suiwer metafories ('purely metaphorical narratives'; kyk Borg 2001:46). Alhoewel hierdie vertellings suiwer metafories is, kommunikeer hulle 'n (metaforiese) waarheid (bv. dat God lewe skep en onderhou). Waarheid, volgens Borg, moet dus nie met feitlikheid verwar word nie. Inteendeel, om metaforiese vertellings as feitlik te lees, is om hierdie vertellings van hulle bedoelde boodskap te stroop en die aanspraak wat die Woord van God op ons maak, te ontmagtig (Borg 2003:49-57). ${ }^{7}$

Ten slotte, wat is volgens Borg die funksie van die Bybel? Die funksie van die Bybel, oordeel Borg, is soos die funksie van 'n sakrament. Soos 'n sakrament 'n sigbare teken van God se genade is - 'n brug na God - so is dit met die Bybel. Die Bybel is soos ' $n$ brug tussen God en die gelowige - dit waardeur die Gees aanhou om met ons te praat. Met die lees van die Bybel maak die Gees Christus en God in ons lewens teenwoordig, en word ons getransformeer om in te val by God se plan met sy wêreld en met ons (Borg 2003:57-59). So verstaan, het die Bybel gesag vir die gelowige.

Bogenoemde standpunte oor die oorsprong van die Bybel, hoe die Bybel geïnterpreteer behoort te word, en wat die funksie van die Bybel is, beskou Borg (2003:7-14) as tipies van dit wat hy as die 'emerging paradigm' (opkomende paradigma) beskou wat Skrifbeskouing en Skrifhantering betref. Hierdie paradigma staan in skerp kontras met die 'earlier paradigm' (vroeëre paradigma), waarin die Bybel as onfeilbaar ('foutloos') beskou is, heilig in terme van sy

6.Vir voorbeelde van hoe Borg tekste in die Bybel wat hy as metafories beskou interpreteer, kyk Borg (2001; 2003; 2006; 2011).

7.Saam beskou, is Borg se hermeneutiese uitgangspunt dus dat die Bybel historiesmetafories gelees moet word. Vir sy verduideliking van hierdie hermeneutiese benadering, kyk Borg (2001:37-48). oorsprong gesien word en nie in terme van sy status en funksie nie, meganiese geïnspireer is, en die teks van die Bybel letterlik gelees moet word (kyk ook Borg 2001:3-11).

\section{Skrifbeskouing en Skrifhantering: Die NHKA}

Ter wille van eenvormigheid en die logiese struktuur van hierdie bydrae, word hieronder, soos in die geval van Borg (kyk § 2), aandag gegee aan die Hervormde Kerk se standpunte ten opsigte van Skrifbeskouing en Skrifhantering aan die hand van dieselfde temas as hierbo: die oorsprong van die Bybel, hoe die Bybel geïnterpreteer behoort te word, en dit wat die funksie of gesag van die Bybel is. Die brondokumente wat hierin dien is die Herderlike Skrywe van die Kommissie van die Algemene Kerkvergadering, gestuur aan alle gemeentes van die Kerk in Maart 1997, en die Memorandum oor Skrifbeskouing wat tydens die 67ste Algemene Kerkvergadering gedien het en deur die vergadering sonder verandering aanvaar is (kyk resp. Kommissie van die Algemene Kerkvergadering 1997:1-3, 2004:19-23). ${ }^{8}$

Wat die Hervormde Kerk se verstaan van die oorsprong van die Bybel betref, erken die Kerk dat daar 'n teologiese spektrum van nuanses en oortuigings bestaan rondom die Bybel as Woord van God. Vir die Kerk is dit goed en gesond dat dit so is (Kommissie van die Algemene Kerkvergadering 1997:2). Die Kerk is verder van die oortuiging dat in die totstandkoming van die Bybel, God van mense gebruik gemaak het - mense wat deur die Gees geïnspireer is om oor God te praat (Kommissie van die Algemene Kerkvergadering 1997:4). Hierdie mense het op 'n bepaalde tydstip in die geskiedenis geleef, en is deur hulle tydsomstandighede, wêreldbeeld en kultuur gevorm en beïnvloed. Die Bybel kan daarom beskryf word as God se woord in mensetaal, en bevat soms ook mense se sienings oor en interpretasies van God. Daar is dus 'n menslike kant in en aan die ontstaan van die Bybel, wat beteken dat die woorde in die Bybel nie letterlik die woorde van God self is nie (Kommissie van die Algemene Kerkvergadering 1997:3-4). In die Memorandum, wat voor die 67ste Algemene Kervergadering gedien het, word bogenoemde soos volg uitgedruk:

Ons wil aanvaar dat die Bybel, as 'n verskeidenheid van boeke, die wyse is waarop God kies om te kommunikeer met mense onder bepaalde omstandighede, met hulle besondere wêreldbeeld, hulle eie verstaan van geskiedenis en die werklikheid. Die Bybel is dus God se Woord en kom in mensewoorde na ons toe. As mensewoorde spreek dit ook van bepaalde enkelinge en groepe mense se omstandighede en hulle

8.As amptelike Herderlike Skrywe aan alle gemeentes van die Hervormde Kerk, en aanvaarde memorandum wat by 'n Algemene Kerkvergadering van die Kerk gedien het, word die inhoud van hierdie twee dokumente gesien as die amptelike standkomma van die Hervormde Kerk wat Skrifhantering en Skrifbeskouing betref Die term 'standkomma' moet hier verduidelik word. Skrifbeskouing en Skrifhantering Die term 'standkomma' moet hier verduidelik word. Skrifbeskouing en Skrifhantering is $n$ saak waaroor daar nooit klaar gepraat kan word nie. Tipies van die Hervormde Kerk, is ons uitsprake oor sake altyd voorlopig, en besin ons altyd weer en weer oo hoe ons dink en praat. Die Kommissie van die Algemene Kerkvergadering stel dit dan ook so in die Herderlike Skrywe van Maart 1997: Die Kommissie van die Algemene Kerkvergadering is nie ... die mening toegedaan dat hy oor ' $n$ saak soos hierdie [Skrifbeskouing en Skrifhantering] alles reglynig kan saamvat, in ' $n$ skema kan indwing en sê presies so is dit nie (Kommissie van die Algemene Kerkvergadering 1997:2). 
manier van dink en praat. (Kommissie van die Algemene Kerkvergadering 2004:20)

Die Bybel is dus 'n boek wat in die wêreld ontstaan het, deur die toedoen van swakke, falende en fouterende mense. Verder is dit ook so dat met die oorskryf van die Bybel, wat eeue geduur het, foute ingesluip het. Dit beteken egter nie dat die Kerk die Bybel nie as geïnspireer sien nie, en druk sy standpunt in hierdie verband soos volg uit:

Ons verstaan hierdie hele proses as deur God geïnspireer. Dat die Bybel deur 'n groeiproses ontstaan het, neem niks weg van die gesag van die Woord nie. Inteendeel, dit bevestig op 'n vreemde manier hoe God in menselewens ingegryp het, hoe God met mense besig was en mense gevorm het om oor God te getuig. (Kommissie van die Algemene Kerkvergadering 2004:20)

Uit bogenoemde is dit duidelik dat die Hervormde Kerk nog nooit ' $n$ fundamentalistiese siening van die ontstaan van die Bybel - asof elke woord in die Bybel die direkte woorde van God is - onderskryf het nie. Die Kerk stel daarom duidelik dat hierdie siening voortdurend as verlammend en gevaarlik vir die geloof ontmasker en bestry behoort te word (Kommissie van die Algemene Kerkvergadering 1997:3).

Wat die interpretasie van die Bybel betref, stel die Kerk dit as uitgangspunt dat ' $n$ letterlike lees van die Bybel nog nooit die siening van die Hervormde Kerk was nie. Omdat die Bybel geskryf is deur mense wat deur hulle tydsgewrig en kultuur beïnvloed en gevorm is, kan die leser wat die Bybel wil verstaan daarom nie anders as om hom- of haarself van alle tersaaklike agtergrondgegewens rondom 'n bepaalde Bybelgedeelte te vergewis nie. In die lees van die Bybel moet daar dus altyd op 'n wetenskaplik verantwoordbare wyse so diep as moontlik gegrawe word na alle historiese, taalkundige, kulturele en ander agtergronde wat die betekenis van 'n bepaalde uitspraak of teks in die Bybel mag beïnvloed (Kommissie van die Algemene Kerkvergadering 1997:3-4). In die Memorandum, wat voor die 67ste Algemene Kervergadering gedien het, formuleer die Kerk hierdie aspek van sy Skrifgebruik soos volg:

Hoewel die Bybel oor die grense van plek en tyd 'n boodskap vir alle mense het en die waarheid van die Bybel ook nooit uitgedien raak nie, kan dit nie altyd reglynig op ons eie situasie toegepas word nie. Daar is 'n verskil in kontekste tussen toe en nou en 'n kloof van eeue se geskiedenis wat in ag geneem moet word. Dit vra van ons vertolking en uitleg om die boodskap van toe ook vir ons tyd te verstaan en toe te pas en om die groot gaping in tyd tussen ons en die Bybelskrywers sinvol te oorbrug. (Kommissie van die Algemene Kerkvergadering 2004:22)

Om genoemde groot gaping in tyd tussen ons en die Bybelskrywers sinvol te oorbrug, oordeel die Kerk dat die Bybel in ons tyd met die beste metodes waaroor die taalwetenskap beskik, geanaliseer moet word (Kommissie van die Algemene Kerkvergadering 2004:20).

Dit is verder die Kerk se standpunt dat die leser van die Bybel, om die gesagvolle spreke van God in ons eie tyd te verneem, in die Bybelse tekste moet onderskei tussen die kontingente (kultuur) en die normatief-konstante (evangelie) wat op sigself midde in die histories kontingente manifesteer. Om die histories-kontingente (bv. kultuurpatrone soos die dra van 'n sluier) vir alle tye normatief te maak, kom daarop neer om kultuur tot evangelie te verklaar (Kommissie van die Algemene Kerkvergadering 1997:6). Die Kerk is daarom van die oortuiging dat die Bybel nie 'n tydgebonde boek is met ' $n$ aantal voorskrifte vir destydse gelowiges wat net so vir ons vandag geld nie. Inteendeel, die Bybel word altyd weer deur die werking van die Gees, die lewende Woord van God wat mense in Christus tot 'n ontmoeting met God bring en oproep om 'n bepaalde etiese lewe te lei (Kommissie van die Algemene Kerkvergadering 2004:20).

Wat, ten slotte, die funksie en gesag van die Bybel betref, beskou die Kerk die Bybel as die bron en die norm vir die kerklike verkondiging en die belangrikste teks vir teologiebeoefening (Kommissie van die Algemene Kerkvergadering 2004:20). Dit is verder die Kerk se oortuiging dat alles wat nodig is om te kan gloen God te kan prys in die Bybel aan gelowiges bekendgemaak word. Die gesag van die Woord is nie geleë in die foutloosheid van die Bybel nie, maar in die ervaring dat die lewende God self, deur sy Heilige Gees, die dooie letters, woorde, verhale en boeke van die Bybel vir die leser as sy lewende Woord laat hoor (Kommissie van die Algemene Kerkvergadering 1997:4). Vir die Hervormde Kerk bepaal die Bybel daarom 'ons hele lewe, ons geloofs- en lewenshouding, asook ons oortuigings en houding ten opsigte van al die dinge en gebeure om ons heen' (Kommissie van die Algemene Kerkvergadering 1997:1).

\section{Vergelyking tussen Borg en die Hervormde Kerk wat Skrifbeskouing en Skrifhantering betref}

Wanneer die standpunte van Borg en die Hervormde Kerk oor Skrifbeskouing en Skrifhantering met mekaar vergelyk word, is daar ooglopende ooreenkomste. Die volgende kan gelys word.

Wat die oorsprong van die Bybel betref, staan beide afwysend teenoor 'n fundamentalistiese siening van die ontstaan van die Bybel, en is beide van die oortuiging dat:

- die Bybel se oorsprong menslik is in dat God van mense, deur die Gees geïnspireer, gebruik gemaak het om oor God te getuig en praat;

- die Bybel nie God se 'absoluut geopenbaarde waarheid' of die direkte woorde van God bevat nie, maar gelowiges se getuienis en nadenke oor God is. Die Bybel is dus God se woord in mensetaal, wat ook soms mense se sienings oor en interpretasies van God insluit;

- die mense wat die boeke van die Bybel geskryf het se verstaan van God en hulle wêreld het plaasgevind vanuit 'n bepaalde plek en tyd, en word uitgedruk deur middel van taal en kulturele konsepte wat deel was van daardie wêreld;

- die Bybel deur 'n groeiproses ontstaan het; en

- die Bybel geïnspireer is in die sin dat die Gees van God so in mense gewerk het dat hulle oor God getuig het soos wat hulle het. 
Wanneer dit by die interpretasie van die Bybel kom, is die ooreenkomste in oortuiging die volgende:

- beide wys 'n letterlike lees van die Bybelse teks sterk af; en

- beide is van oordeel dat 'n historiese lees van die teks onontbeerlik is vir verantwoordelike eksegese.

Ten slotte, wat die gesag en funksie van die Bybel betref, oordeel beide dat:

- die Bybel die fondasie van die Christelike godsdiens is, dit wat die Christelike geloof se identiteit bepaal, en bepalend is vir die Christelike etiek;

- die funksie van die Bybel met die funksie van 'n sakrament vergelyk kan word. Met die lees van die Bybel maak die Gees Christus en God in ons lewens teenwoordig; dit dien as ' $n$ brug tussen ons en God, en in die Woord, deur die Gees, hoor ons die lewende woorde van God; en

- in die lees van die Bybel onderskei moet word tussen kontingente kultuurwaardes en die normatief-konstante (evangelie). Die Bybel is dus nie 'n tydlose boek wat etiese optrede vir alle tye insluit nie.

Uit bogenoemde kan nie anders afgelei word dat Borg in wese eintlik 'n goeie Hervormer was nie! Feitlik geen verskil kan aangetoon word tussen sy en die Hervormde Kerk se standpunte ten opsigte van Skrifbeskouing en Skrifhantering nie. Die Hervormde Kerk se Skrifbeskouing en Skrifhantering pas mooi in by wat hy as die 'opkomende paradigma' beskou, alhoewel hierdie hermeneutiese paradigma, vir die Hervormde Kerk, nie opkomend is nie, maar lankal reeds bestaan.

\section{Metaforisiteit}

Waar daar wel 'n verskil tussen die Hervormde Kerk en Borg se Skrifbeskouing en Skrifhantering blyk te wees, is Borg se klem op die metaforisiteit van die Bybelse teks. Soos hierbo aangetoon, oordeel Borg dat die metaforisiteit van die Bybelse teks op drie wyses manifesteer: die Bybel bevat duidelike metaforiese beelde (bv. God is 'n vader, en Jesus is 'n wingerdstok), vertellings wat historiese gebeure metafories aanbied, en 'suiwer' metaforiese vertellings wat nie as feitlik gelees moet word nie. Hierdie vertellings, alhoewel 'suiwer' metafories, kommunikeer altyd 'n bepaalde waarheid, en in die lees van hierdie vertellings moet na hierdie waarheid gesoek word eerder as om hierdie vertellings as feitlik en histories te lees. Wanneer laasgenoemde gebeur, stroop die leser hierdie vertellings van hul bedoelde boodskap en die aanspraak wat die Woord van God op ons maak.

Die feit dat die Hervormde Kerk in bogenoemde twee amptelike dokumente nie na die metaforisiteit van tekste in die Bybel verwys nie, beteken egter nie dat sommige Bybelwetenskaplikes in die Hervormde Kerk wel op hierdie wyse die Bybel interpreteer nie. Verskeie publikasies oor die metaforisiteit van die Bybelse teks het al uit die pen van Hervormde Bybelwetenskaplikes verskyn. Hieronder word twee voorbeelde van hierdie wyse van Skrifinterpretasie aangebied; die eerste van Handelinge 7:48a, 'n teks wat dit wat histories gebeur het metafories aanbied (kyk Van Aarde 1991:51-64), en Matteus 14:22-33, 'n teks wat as suiwer metafories verstaan sou kon word (kyk Van Eck 2011:152-163).
Wat Handelinge 7:48a ${ }^{9}$ betref, oordeel Van Aarde dat hierdie uitspraak van Stéfanus metafories verwys na Jesus se verbreding van die tempel (waar God net volgens sommiges teenwoordig was) om ook die sogenaamde onreines en sosiaalveragtes van sy dag in te sluit. In die tyd van Jesus was die Sadduseërs van die oortuiging dat alleen hulle, wat rein (heilig) soos God was, in die tempel mag gekom het. Mense met, byvoorbeeld, liggaamlike gebreke of melaatsheid - die sogenaamde sondaars of onreines - kon nie in die tempel in God se teenwoordigheid verskyn nie. Jesus het egter, soos dit duidelik uit die evangelies blyk, met hierdie sogenaamde onreines gemeng, en God by hulle, buite die tempel, teenwoordig verklaar. Hierdie uitgestote onreines mag wel nie in die tempel, wat met hande gebou is, gekom het nie, maar God was, volgens Jesus, by hulle teenwoordig. Hoekom? Want God, volgens Jesus, was nie in die eerste plek heilig nie, maar barmhartig. Omdat Jesus God so verstaan het, anders as hulle wat in beheer van die tempel was, het Hy God ook teenwoordig gesien by hulle wat buite die tempel moes staan. God het dus nie meer net in die tempel gewoon nie, maar ook buite die tempel. Daarom het Jesus Hom veral geskaar by hulle wat nie in die tempel mag gekom het nie, en buite die tempel aan hierdie 'veragtes' verkondig dat God ook by hulle is; want God is immers in die eerste plek barmhartig en nie heilig nie.

Hierdie historiese gebeure, volgens Van Aarde, word deur Stéfanus in sy toespraak in Handelinge 7 metafories aangebied. Die tempel wat met hande gebou is verwys na die tempel in Jerusalem, en God, aldus Stéfanus, woon juis nie in sulke tempels nie. Hy woon (is teenwoordig) juis buite dit; ook by almal wat volgens die tempelpriesters en Sadduseërs nie in God se teenwoordigheid mag kom nie. Dit is moontlik, impliseer Stéfanus, op grond van wat Jesus gedoen en verkondig het. Geskiedenis word metafoor; 'n metafoor wat een iets sê maar iets anders bedoel (kyk Van Aarde 1991:51-64). ${ }^{10}$

Matteus $14: 22-33$ is ' $n$ vertelling waarin beskryf word hoe Jesus op die water loop en 'n storm laat bedaar. Hierdie vertelling sou verstaan kon word as 'n nie-histories metaforiese vertelling. ${ }^{11}$ Vanuit hierdie perspektief is dit dus 'n vertelling wat nie noodwendig feitlik of histories geïnterpreteer hoef te word nie, maar eerder ondersoek moet word in terme van die betekenis wat dit as metaforiese vertelling wil oordra; met ander woorde, dit 'wat dit wil sê'.

'n Letterlike lees van hierdie vertelling sal beklemtoon dat wat in die vertelling beskryf word, werklik gebeur het. Jesus, en Petrus, het op water geloop. Met hierdie as fokus, wat sou

9.'Maar die Allerhoogste woon nie in tempels wat met hande gemaak is nie' (Hand 7:48a)

10.Van Aarde (1991:55), in navolging van Sally McFague, beskryf 'n metafoor soos volg: A metaphor exists when one thing is seen as another, when one pretends that this is that because one does not know how to talk about this, and consequently uses that to talk about this. Metaphorical use of language is when one pretends that a similarity exists between two different objects, issues, events and the like, where one similarity exists between two different objects, issues, events and the like, where one to, in a manner of speaking, say more about the one one knows less about'.

11.Vir ' $n$ meer volledige interpretasie van Matteus 14:22-33 as 'n nie-historiese metafoor, kyk Van Eck (2011:160-163). Met die term 'nie-historiese metafoor' word nie bedoel dat die historisiteit van die metafoor in beginsel in twyfel getrek word nie. Wat wel met hierdie term bedoel word, is dat die historisiteit of letterlike verstaan van die vertelling nie die fokus van verstaan is nie. 
die vertelling beteken? Dat ons hier met 'n wonderwerk te make het? Of dat, indien ons geloof groot genoeg is, ons ook op water behoort te kan loop?

'n Metaforiese verstaan van die vertelling, daarenteen, fokus op die moontlike betekenis van die vertelling. Om iets van hierdie betekenis te snap, is dit nodig om die godsdienstige konteks waarin hierdie gebeure afspeel in berekening te bring. Uit die vertelling is dit duidelik dat die dissipels Jesus as Seun van God bely aan die einde van die gebeure omdat Hy mag het oor die wind en die see. In die Ou Nabye Ooste (wat Israel ingesluit het), is die see gesien as 'n simbool van chaos. In die Babiloniese skeppingsvertelling (bekend as die Enuma Elish) word vertel dat Mardoek die aarde geskep het deur Tiamat, die godin van die see, te oorwin. Die skepping was dus die gevolg van die oorwinning oor die chaosmagte (see). In die Ugaritiese Baälgodsdiens word die skepping op dieselfde wyse beskryf: Baäl skep deurdat hy Jamm, die god van die see, oorwin. 'n Verdere ooreenkoms in die skeppingsverhale van die Babiloniese en Ugaritiese godsdienste is dat Tiamat in twee geskeur word, en Jamm uitmekaar geskeur word wanneer hulle oorwin word. So word die waters (die seegod) van mekaar geskei, met droë grond wat bewoonbaar is tussenin.

Ons vind in Genesis 1 dieselfde beskrywing van die skepping. In Genesis 1:2 word gestel dat die aarde voor die skepping onbewoonbaar was, dat dit donker op die diep waters was, en dat God se Gees oor die waters gesweef het. In Hebreeus is die woorde wat vir woes en diep gebruik word tohu en tehom. Verskeie Ou-Testamentiese geleerdes oordeel dat die woord tohu [woes] en tehom [diep] 'n verwysing is na die seegodin Tiamat. Volgens Genesis 1:6-10 skep God die bewoonbare aarde deur te begin om die woeste en diep waters (tohu en tehom $=$ Tiamat) van mekaar te skei. God plaas 'n 'gewelf' (hemel; Gen 1:8) tussen die waters, en verplaas die waters na bo die hemel en onder die hemel. Daarna laat God die waters onder die hemel bymekaarkom sodat daar droë grond kan wees ('aarde') wat bewoonbaar is (Gen 1:9-10). Dus, wil die skeppingsvertelling in Genesis 1 sê, is dit God wat geskep het, en nie Mardoek (of Baäl) nie.

Vir Israel was God dus die ware en enigste God omdat Hy die chaosmagte, die waters, oorwin het. Net God kan dit doen, daarom is Hy God. En wat gebeur in Matteus 14:22-33? Jesus oorwin die waters soos God dit gedoen het! En dit kan net een ding vir die dissipels beteken: Jesus is God!

Hierdie moontlike betekenis van die vertelling in Matteus 14:22-33 sal nie raakgesien word wanneer die vertelling bloot letterlik gelees word nie. 'n Metaforiese lees van die vertelling bring egter die betekenis na vore dat die dissipels Jesus hier as God erken omdat Hy mag het oor die storm en die see. Juis daarom kniel hulle voor Hom en bely dat Hy die Seun van God is.

\section{Slotopmerkings}

In die lig van bogenoemde metaforiese interpretasies in die Hervormde Kerk, is dit duidelik dat daar weinig, indien enige, verskille bestaan wat betref die Skrifbeskouing en Skrifhantering van Marcus Borg en die Hervormde Kerk. Miskien moet hierdie ooreenkoms en vergelyking meer presies gestel word. Marcus Borg se Skrifbeskouing en Skrifhantering verskil weinig van die van die Hervormde Kerk, aangesien dit wat Borg as die 'opkomende paradigma' sien, lankal reeds vaardig is in hoe Hervormde teoloë die Bybel lees en verstaan. Bogenoemde bespreking van die Skrifbeskouing en Skrifhantering van Marcus Borg en die Hervormde Kerk stel dit verder duidelik dat Borg nie, soos baie geoordeel het en miskien nog steeds oordeel, modernisties-krities in sy interpretasie van die Bybel is nie.

Die Hervormde Kerk se Skrifbeskouing en Skrifhantering is nie net tipies van die Hervormde Kerk se dialekties-teologiese nadenke nie, maar ook 'n kosbare skat waaraan vasgehou word. Omdat die Kerk altyd dialekties-teologies met die Bybel omgaan, is die Kerk se huidige Skrifbeskouing en Skrifhantering ook niks anders as 'n standkomma nie, en nooit ' $n$ afgehandelde standpunt nie. Die Kerk erken immers dat daar ' $n$ teologiese spektrum van nuanses en oortuigings rondom die Bybel as Woord van God bestaan - 'n erkenning wat goed en gesond vir die Kerk is. Die Kerk het nooit klaar gedink nie. En wanneer die Kerk dink, en weer dink, doen die Kerk dit met die oortuiging dat die Bybel die bron en die norm vir die kerklike verkondiging en die belangrikste teks vir teologiebeoefening is.

\section{Erkenning Mededingende belange}

Die outeur verklaar dat sy geen finansiële of persoonlike verbintenis het met enige party wat haar nadelig kon beïnvloed het in die skryf van hierdie artikel nie.

\section{Literatuurverwysings}

Borg, M.J., 1987, Jesus, a new vision: Spirit, culture, and the life of discipleship, HarperOne, San Francisco, CA.

Borg, M.J., 1994, Meeting Jesus again for the first time: The historical Jesus and the heart of contemporary faith, HarperOne, San Francisco, CA.

Borg, M.J., 2001, Reading the Bible again for the first time: Taking the Bible seriously but not literally, HarperSanFrancisco, New York.

Borg, M.J., 2003, The heart of Christianity: Rediscovering a life of faith, HarperSanFrancisco, New York.

Borg, M.J., 2006, Jesus: Uncovering the life, teachings, and relevance of a religious revolutionary, HarperCollins, New York.

Borg, M.J., 2011, Speaking Christian: Why Christian words have lost their meaning and power-And how they can be restored, HarperOne, San Francisco, CA.

Borg, M.J. \& Wright, N.T., 1999, The meaning of Jesus: Two visions, HarperOne, New York.

Kommissie van die Algemene Kerkvergadering, 1997, Herderlike skrywe van die Kommissie van die Algemene Kerkvergadering aan alle gemeentes, Maart 1997.

Kommissie van die Algemene Kerkvergadering, 2004, Memorandum oor Skrifbeskouing: Die Bybel - God se woord vir ons tyd. Gedagtes van die Kerk oor Skrifbeskouing, Agenda van die 67ste Algemene Kerkvergadering, pp. 19-23.

Tatum, W.B., 1999, In quest of Jesus, Abingdon Press, Nashville.

Van Aarde, A.G., 1991, "'The most high God live in houses, but not houses built by men...": The relativity of the metaphor "temple" in Luke-Acts', Neotestamentica 25(1), 51-64.

Van Eck, E., 2011, 'Metaforiese vonke en mitologiese taal', in C. Vos \& D.J. Human (reds.), Vaste rots op wie ek bou, pp. 152-163, Lux Verbi.BM, Kaapstad.

Van Wyk, D.J.C. (Jr.), 1995, 'Marcus Borg oor die opstanding van Jesus', Die Hervormer, Desember 1995, 2 